\title{
NILAI-NILAI PENDIDIKAN MULTIKULTURALISME \\ PADA MUSIK TRADISIONAL TALI DUA \\ DI PULAU BATANG DUA KOTA TERNATE MALUKU UTARA
}

\author{
Vega Ricky Salu \\ Program Pascasarjana, Universitas Negeri Semarang \\ E-mail: vegajazzsalu@yahoo.com
}

\begin{abstract}
Abstrak
Pendidikan Multikultural dalam konteks keindonesiaan memiliki peran dan fungsi yang sangat penting. Sebagai negara yang memiliki keberagaman budaya, masyarakat rentan dengan konflik sosial. Salah satu keberagaman itu terdapat Pulau Batang Dua. Masalah dalam penelitian ini adalah bagaimana nilai-nilai musik tradisional Tali Dua dan bagaimana nilai-nilai pendidikan multikulturalisme pada musik tradisional Tali Dua di Pulau Batang Dua, Ternate, Maluku Utara dapat dilakukan. Metode penelitian menggunakan pendekatan kualitatif. Teknik pengumpulan data menggunakan observasi, wawancara, dan studi dokumen. Analisis data yang digunakan adalah verifikasi data, reduksi data, dan penyajian data. Hasil penelitian menunjukan, bahwa nilai-nilai pendidikan multikulturalisme dapat dilihat dalam fungsi musik Tali Dua pada acara perkawinan dan acara Lawidi. Nilai pendidikan multikulturalisme juga terdapat pada internal kelompok musik Tali Dua, yakni setiap karakter dan kultur anggota yang berbeda menyatu dalam kelompok musik Tali Dua sebagai nilai-nilai budaya bangsa yang harus dijaga, dilestarikan, dan dikembangkan.
\end{abstract}

Kata kunci: pendidikan multikultural, musik tradisi, Musik Tali Dua

\section{EDUCATIONAL VALUES OF MULTICULTURALISM \\ IN TALI DUA TRADITIONAL MUSIC IN BATANG DUA ISLAND, TERNATE CITY, NORTH MALUKU}

\begin{abstract}
Multicultural education in Indonesia has a very important role and function. As a country with cultural diversity, people are vulnerable to social conflict. One of the diversities is in Batang Dua Island. The problems in this research are how the traditional musical values of Tali Dua and the values of multicultural education on Tali Dua traditional music in Batang Dua Island, Ternate, North Maluku can be done. The method used in this research is the qualitative approach. Data collection techniques used in this research are observation, interviews, and document studies. Data analysis involves data verification, data reduction, and data presentation. The results showed that the values of multicultural education can be seen in the function of Tali Dua music at the wedding ceremony and Lawidi event. The value of multicultural education is also found in the musical group of Tali Dua, that is, each character and culture of different members converge in the group as the nation's cultural values that must be maintained, preserved, and developed.
\end{abstract}

Keywords: multicultural education, traditional music, Tali Dua Music 


\section{PENDAHULUAN}

Indonesia merupakan salah satu negara di dunia yang sangat beragam, jika dilihat dari banyaknya budaya, etnis, bahasa daerah, sistem kepercayaan, kesenian dan berbagai macam karakter yang dimiliki masyarakat. Tidak satu pun daerah atau wilayah di Indonesia yang tidak memiliki kesenian tradisi dan bahasa daerah. Mulai dari Sabang sampai Merauke tiap-tiap memiliki budaya tradisi, kesenian tradisi, dan bahasa daerah, sebagai identitas dan kearifan lokal. Dari segi bahasa, Indonesia memiliki ratusan bahasa daerah di tiap-tiap kota, kecamatan, bahkan kelurahan. Pengetahuan terhadap perbedaan bahasa sebagai produk budaya menjadi sangat penting bagi generasi muda dalam membentuk karakter bangsa. Hjlemslev (dalam Sunarto, 2016: 28), mengatakan bahwa ciri yang menonjol dari bahasa adalah bentuk hubungannya dengan substansi (pemaknaan). Artinya, akan terjadi kesalahpahaman jika komunikator dan komunikan tidak saling memahami bahasa satu dengan yang lainnya. Oleh karena itu, pengetahuan terhadap bahasa daerah lain sebagai produk budaya, harus benar-benar dipahami, agar tidak terjadi salah komunikasi yang dapat menimbulkan konflik sosial. Itu dari aspek bahasa, bagaimana dengan musik tradisi? Pasti lebih banyak lagi.

Keberagaman budaya merupakan anugerah dan kekayaan bangsa yang patut di syukuri, tetapi sekaligus menjadi ancaman yang sangat mengerikan jika tidak dikelola dengan baik. Pengalaman sejarah bangsa di beberapa daerah adalah bukti sejarah bahwa bangsa ini pernah mengalami bencana dan krisis kemanusiaan yang menyakitkan, sebagai akibat dari pengelolaan keberagaman yang salah di maksud. Perang agama atau kerusuhan di Maluku dan Maluku Utara tahun 1999, misalnya merupakan satu bukti sejarah dari sekian banyak bukti lainnya. Perbedaan suku (Loloda, Tobaru, Jawa, Minahasa dan lainnya) serta agama (Islam dan Kristen) di Maluku dan Maluku Utara digunakan provokator sebagai alat untuk menghancurkan persatuan hidup orang basudara. Kenyataan saat ini menunjukan isu-isu terhadap ancaman persatuan dan kesatuan sangat rentan terjadi. Peran media sosial sebagai pemberi informasi dan wawasan kebangsaan, berubah menjadi objek penularan pesan provokatif, pemimpin bangsa yang harusnya menjadi panutan masyarakat menunjukkan sikap-sikap yang tidak toleran dalam menanggapi persoalanpersoalan dan masalah-masalah agama. Bahkan lebih parah lagi ketika momen politik, para pemangku kepentingan tidak segan-segan memakai perbedaan budaya, agama, ras, dan etnis tertentu sebagai senjata yang ampuh untuk mencapai kepentingan dan kepuasannya.

Pada segi lain, realitas generasi muda sebagai penerus tongkat estafet bangsa ini lebih mencintai kebudayaan bangsa lain yang tecermin dalam penampilan, sikap dan perilaku, gaya hidup, dan sifat egoistis individu yang tak terkontrol. Dampak dari sikap kurang peduli terhadap budaya bangsa adalah hilangnya kesenian tradisional, meski di dalamnya terkandung nilai-nilai budaya yang sangat berarti bagi eksistensi manusia. Hal ini seperti yang dijelaskan Jazuli (2001), bahwa sesungguhnya kesenian tradisi banyak memberikan harapan, kemanfaatan, dan kebermaknaan bagi kehidupan manusia, tetapi realitas yang terjadi dewasa ini menunjukan bahwa banyak seni tradisional yang kurang mendapat perhatian dari pemerintah dan masyarakat pemiliknya sendiri.

Hartanto (2005: 1) menjelaskan bahwa persatuan bangsa bagi negara kebangsaan seperti Indonesia merupakan syarat utama kelestarian dan keberadaan negara itu. Oleh sebab itu, segala sesuatu yang mengarah kepada kesatuan bangsa penting untuk mendapatkan perhatian sebagai sumbangan lebih kekarnya persatuan bangsa dan kesatuan negara. Kini kiranya sulit bagi seorang penduduk di Maumere mengenal musik saudaranya yang di Aceh; atau seorang di Manado mengenal musik saudaranya di Bayuwangi. Tidak hanya itu, bahkan pada masa sekarang, masa kemajuan komunikasi yang demikian pesat, tidak jarang penduduk Kota Bandung tidak mengenal Goong Renteng di Bandung Selatan. Kalau suku bangsa satu tidak mengenal musik suku bangsa lain sangat dimungkinkan mereka juga 
tidak saling mengenal dalam segala aspek budaya masing-masing. Situasi semacam ini merupakan salah satu titik rawan bagi kesatuan negara kebangsaan. Jika mereka tidak saling mengenal bagaimana dapat saling menghargai, dan saling memiliki. Padahal budaya milik suku-suku bangsa adalah milik seluruh bangsa Indonesia (Hartanto 2005: 2). Dengan demikian, musik tradisi memiliki peran dan fungsi yang sangat penting dalam merawat persatuan dan kesatuan bangsa dengan tetap mengedepankan pemahaman multikultural dan sikap toleransi terhadap keberagaman. Musik tradisi memiliki nilai-nilai hidup yang dapat dijadikan pedoman bagi terciptanya suatu bangsa yang aman dan damai.

Menurut Sumaryanto (2016: 53) musik tradisi sebagai olah budi, rasa dan karsa dari masyarakat budaya merupakan ruang refleksi yang menemukan nilai-nilai hidup. Nilai-nilai inilah yang membentuk mentalitas pribadi dan sebagai acuan tatanan hidup dalam berkomunikasi. Sejalan dengan itu, Sutrisno (2010) menawarkan suatu pendekatan budaya. Pendekatan ini melihat suatu realitas dari masyarakat dari sudut pandang mentalitas orang, nilai yang diacu suatu individu bersama. Penyatuan nilai merekatkan bangsa majemuk dengan keikaan, saling hormat menghormati, toleransi pada perbedaan, serta hak hidup etnik, baik agama dan golongan tertentu tanpa saling mendeskriminasikan satu dengan yang lain.

Kenyataan-kenyataan ini tentunya sangat membahayakan eksistensi bangsa yang berfalsafah "berbeda-beda tetapi satu" (Bhineka Tunggal Ika), jika tidak diperhatikan dan di atasi secara serius. Oleh karena itu, Indonesia membutuhkan media yang efektifmelalui pranata sosial, untuk menumbuhkan kesadaran terhadap keberagaman dan pluralitas terhadap masalah di atas. Salah satu pranata sosial dimaksud adalah melalui pendidikan, baik formal, nonformal, dan informal. Pendidikan secara formal, nonformal, dan informal oleh Rohidi, (2014: 158-159) dijelaskan sebagai berikut: (1) Pendidikan formal, yaitu ketika dilaksanakan secara teratur, terstruktur, dan terancang dalam jangka masa tertentu secara bertahap. Pendidikan formal umumnya berlaku di sekolah, walaupun juga dapat berlaku di rumah dan di masyarakat. (2) Pendidikan nonformal biasanya diselenggarakan di lingkungan masyarakat, berlangsung bagi pencapaiaan suatu kemahiran tertentu, dan lazimnya dirancang dalam jangka waktu yang singkat. Pendidikan nonformal umumnya dilaksanakan di kalangan masyarakat, walaupun mungkin saja dilakukan di sekolah atau di dalam keluarga. (3) Pendidikan informal ialah segala sesuatu aktivitas, yang melibatkan dua atau lebih individu, yang tak terancang namun justru berdampak pada perubahan perilaku. Pendidikan informal berlaku sebagai sebuah peristiwa, baik disadari maupun tidak disadari, lebih membentuk perilaku-perilaku tertentu. Selain itu, Mead dalam (Rohidi, 2011: 55) menegaskan bahwa pendidikan semestinya menunjukan dua fungsi utama, yaitu melestarikan pada satu segi, dan pada segi lain mengembangkan nilai-nilai, kepercayaan, dan pengetahuan sesuai dengan kebutuhan individu, sosial, dan budaya para warga masayarakat, yang hasilnya tercermin dengan jelas dalam cara berfikir, berbicara, bersikap atau menghayati, dan bertindak. Oleh karena itu, pendidikan sebagai pranata sosial, baik formal, nonformal, dan informal, sebaiknya mendasari proses mendidik dengan nilai-nilai dan budaya tradisi, sistem kepercayaan, dan pengetahuan sehingga menghasilkan manusiamanusia yang holistik secara individu, sosial, dan berbudaya.

Sifat pendidikan itu harusnya dipahami sebagai seperangkat sistem yang utuh. Artinya, semua sifat pendidikan ini harus menjalankan fungsi dan perannya sebagai pranata sosial yang mampu memasukan nilai-nilai budaya dalam konteks keberagaman dan pluralitas sebagaimana dijelaskan di atas. Sejalan dengan itu, Rohidi (2011: 59) menjelaskan, di negaranegara yang bangsanya bersifat majemuk atau heterogen, pendidikan apreasiasi dalam bentuk atau dalam konteks konsep pendidikan multikultural, menjadi cara yang dipilih untuk mewujudkan sebuah bangsa yang terintegrasi dengan mantap, yang diharapkan masyarakatnya memiliki kesadaran atau toleransi kuat terhadap hadirnya perbedaan-perbedaan, dalam kesatuan dan persatuan. 
Pendidikan multikultural (Triyanto, 2017), berasal dari ideologi konservatif. Ideologi konservatif, terutama dalam dunia pendidikan, memunculkan paham ideologi konservatisme dan multikulturalisme. Ideologi konservatisme pendidikan mendukung nilai-nilai tradisional, arahnya lebih ditekankan pada pendekatan menjaga, mewarisi, melestarikan, memelihara, dan mengamalkan nilai-nilai tradisional yang ada. Sedangkan ideologi pendidikan multikulturalisme, arah dan penekanannnya bukan hanya bersumber pada nilai-nilai tradisi (menjaga, mewarisi, dan melestarikan), tetapi pemahaman terhadap nilai-nilai tradisi itu menjadi penting ketika diwujudkan dalam action atau tindakan nyata, melalui sikap dan perilaku yang mau menerima keberagaman tradisi yang ada dilingkungan sekitar.

Hal itu dapat dilihat dalam pendapat (Damerath \& Mattheis 2012) bahwa secara antropologis, pada masayarakat yang pluralistik, nilai-nilai multikultural yang terwujud dalam kesadaran bersikap dan berperilaku untuk menghargai dan menerima keanekaragaman atau perbedaan budaya ini penting disosialisasikan atau ditanamkan karena itu dapat menjadi pengikat persatuan dan kesatuan serta kesetaraan (equity) dalam menjalankan kehidupan bermasyarakat, berbangsa, dan bernegara, secara demokratis, tanpa prasangka, tidak diskriminatif, dan menghargai hak asasi (Mahmud, dalam Triyanto, 2017: 135).

Terdapat titik temu antara tujuan pendidikan multikultural dengan tujuan pendidikan seni di ranah apresiasi. Esensi pendidikan multikultural adalah praktik pengenalan dan penanaman nilainilai yang berorientasi pada tujuan terbentuknya kesadaran bersikap dan berperilaku untuk menghargai dan menerima keberagaman atau perbedaan budaya. Ini pernting disosialisasikan atau ditanamkan karena dapat menjadi pengikat persatuan dan kesatuan dalam menjalankan kehidupan bermasyarakat, berbangsa, dan bernegara secara demokratis, tanpa prasangka, tidak diskriminatif, dan menghargai hak asasi. Sementara itu, pendidikan apresiasi, esensinya adalah juga praktik pengenalan, pemahaman, dan penanaman nilai-nilai yang bermuara pada tujuan tumbuhnya sikap dan kesadaran menghargai karya seni dari mana pun yang diciptakan oleh siapapun tanpa melihat daerah asal atau etnisnya. Kegiatan apresiasi seni, sebagai tindakan sosial untuk mengenali, memahami, menikmati, dan menghargai di sini mempersyaratkan tiadanya sikap apriori (tanpa prasangka), kepedulian, perhatian, dan kesadaran seseorang, merupakan modal budaya yang tepat dalam membangun kesadaran menghargai dan menerima keanekaragaman atau perbedaan berbagai jenis, bentuk, corak, atau gaya seni (Triyanto, 2017: 136). Kesadaran terhadap keanekaragaman dan perbedaan budaya suatu masyarakat dapat diterapkan melalui proses apresiasi budaya, yang berakar pada budaya tradisi tiap-tiap daerah, khususnya musik tradisi.

Nilai-nilai musik tradisi sebagaimana dijelaskan Supanggah (2016: 8) dapat ditanamkan melalui belajar dan berolah karawitan. Melalui ini seseorang akan mendapatkan nilai-nilai (tambah) yang bukan saja bermusik dan berakademik, tetapi nilai-nilai yang telah beberapa tahun tidak lagi di dapatkan. Nilai-nilai itu antara lain: Memupuk rasa kekeluargaan, memupuk perasaan berada (being) dalam satu komunitas, semangat kebersamaan, kegotong royongan dengan tidak mengedepankan pamrih pribadi, menekan dan mengurangi sifat dan sikap keegoisan atau individualistis, mempertinggi sikap toleran, kelenturan, tenggang rasa, dalam hidup bermasyarakat, pengendalian emosi, tidak cepat marah atau tersinggung gara-gara hal yang "sepele", dan sebagainya.

Nilai-nilai musik tradisi ini terdapat juga pada musik tradisi Tali Dua, yang merupakan musik tradisional masyarakat Pulau Batang Dua, Ternate, Maluku Utara. Nilai-nilai ini dianalisis dalam konteks pendidikan multikultural sebagai pranata sosial yang menekankan pentingnya sikap menghargai dan toleransi terhadap keberagaman budaya, etnis, suku, bahasa, sistem kepercayaan, dan kesenian tradisi di Indonesia.

Berdasarkan uraian latar belakang di atas, maka masalah yang dikaji dalam tulisan ini adalah bagaimana nilai-nilai musik tradisional 
Tali Dua di Pulau Batang Dua, dan bagaimana nilai-nilai pendidikan multikulturalisme melalui musik tradisional Tali Dua di Pulau Batang Dua, Ternate, Maluku Utara dapat dilakukan?

Hasil penelitian menunjukan nilai-nilai multikulturalisme pada musik Tali Dua terlihat dari fungsi musik Tali Dua dan pada anggota kelompok musik Tali Dua. Metode penelitian menggunakan pendekatan kualitatif. Uraian berikut ini akan membahasnya lebih lanjut.

\section{METODE}

Penelitian ini menggunakan metode kualitatif. Teknik pengambilan data dilakukan melalui observasi, wawancara dan studi dokumen (Rohidi, 2011: 189). Wawancara dilakukan guna memperoleh informasi tentang eksistensi musik Tali Dua di Pulau Batang Dua. Sedangkan studi dokumen digunakan untuk memperoleh dokumen-dokumen terkait foto-foto atau data-data masa lalu. Analisis data dilakukan mulai dari reduksi data, penyajian data, penarikan kesimpulan/verifikasi. Teknik pemeriksaan keabsahan data menggunakan metode triangulasi. Penarikan simpulan dilakukan sesuai dengan catatan-catatan data lapangan yang terkumpul. Dalam reduksi data ini peneliti melakukan proses pemilihan, pemusatan perhatian, penyederhanaan, pengabstrakkan, dan transformasi data kasar yang muncul dari catatan-catatan di lapangan. Reduksi data ini dilakukan secara terus menerus selama proses penelitian. Langkah selanjutnya yaitu penyajian data lengkap, yaitu sekumpulan informasi tersusun yang memberikan kemungkinan adanya penarikan kesimpulan.

\section{HASIL DAN PEMBAHASAN \\ Musik Tradisional Tali Dua}

Indonesia Timur, Maluku Utara, kota Ternate, khususnya kecamatan Pulau Batang Dua, memiliki salah satu musik tradisional yang disebut Musik Tali Dua. Nama musik Tali Dua sering diidentikan dengan nama Pulau Batang Dua, walaupun penyebutan nama musik Tali Dua sesungguhnya di dasarkan pada organologi intrumen musiknya. Instrumen Tali Dua memiliki dua tali senar ukuran no 12 pada intrumen bass (berbentuk seperti Instrumen Cello), dua tali senar inilah yang menyebabkan penyebutan nama musiknya; musik Tali Dua.

Instrumen musik Tali Dua merupakan intrumen yang dimainkan secara berkelompok dalam satu grup berjumlah antara lima sampai sepuluh orang yang terdiri dari berbagai latar belakang karakter dan suku yang berbeda. Kelompok musik Tali Dua memiliki seorang pemimpin yang biasanya disebut ketua kelompok. Ketua kelompok biasanya dipilih secara langsung oleh anggota dengan melihat beberapa persyaratan sederhana yang di sepakati secara bersama. Ketua kelompok musik Tali Dua setidaknya memiliki beberapa kemampuan atau keahlian di antaranya, kemampuan untuk mengorganisasi setiap anggota kelompok, kemampuan memainkan semua instrumeninstrumen yang dipakai dalam kelompok musik Tali Dua, mampu membuat aransemen sederhana lagu-lagu daerah yang akan dimainkan, dan memiliki kemampuan menciptakan lagu daerah sesuai dengan bahasa daerah dan ragam musik yang ada di pulau Batang Dua.

Musik Tali Dua terdiri dari alat-alat musik seperti; gitar akustik, ukulele/juk (yang di buat sendiri), ceker (terbuat dari penutup botol minuman), bas Tali Dua, dan sering di kolaborasi dengan recorder atau juga biola. Biasanya pemain gitar terdiri dari dua sampai tiga orang, pemain ukulele terdiri dari dua sampai empat orang sedangkan pemain ceker dan bass tali dua terdiri dari satu orang. Berikut gambar bentuk musik Tali Dua di Pulau Batang Dua. Berikut pada gambar 1 diperlihatkan bentuk musik Tali Dua di Pulau Batang Dua.

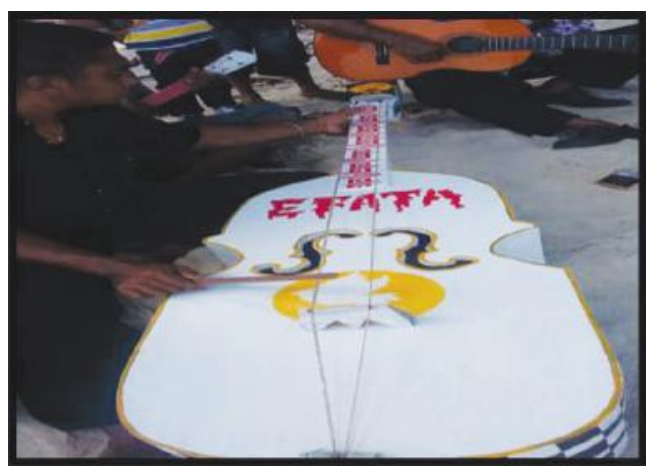

Gambar 1. Bentuk musik Tali Dua 
Sekitar tahun 1970-an masyarakat Batang Dua menggunakan musik Tali Dua pada semua tatanan kehidupan mulai dari kelahiran sampai kematian. Sebagai kesenian tradisi, masyarakat Batang Dua selalu aktif menggunakan musik Tali Dua pada semua kegiatan acara, yang dilakukan oleh warga masyarakat, baik acara syukuran anak masuk Gereja, acara baptisan anak, acara natal dan tahun baru, perayaan pesta ulang tahun, acara masuk minta/peminangan, ritual agama, pernikahan adat, dan acara kematian (malam penghiburan). Berdasarkan wawancara bersama tokoh adat kelurahan Mayau (Bapak Septinus Parang), beliau mengungkapkan bahwa: "Musik Tali Dua dulu itu sekitar taong tujuh puluan torang pake di samua acara, acara apapun itu torang tetap pake Tali Dua”.

Tidakdapat di pungkiri, bahwakemajuan ilmu dan teknologi dewasa ini sangat mempengaruhi eksistensi musik Tali Dua di Pulau Batang Dua, khususnya dari prespektif fungsi dan perannya. Meskipun demikian, nilai-nilai musik Tali Dua tetap diwarisi, di lestarikan, dan di kembangkan oleh masyarakat di Pulau Batang Dua sebagai pedoman hidup mereka. Nilai-nilai musik Tali Dua dibagi atas nilai internal dan nilai eksternal. Nilai eskternal adalah nilai-nilai yang berkaitan dengan pemfungsian dan penggunaan musik Tali Dua oleh masyarakat di Pulau Batang Dua, sedangkan nilai internal, difokuskan pada pemain musik yang tergabung dalam kelompok musik Tali Dua.

\section{Nilai Eksternal Musik Tali Dua}

Nilai eksternal Tali Dua merupakan nilainilai yang ada di luar dari kelompok musik Tali Dua, yaitu pemfungsian dan penggunaan musik Tali Dua pada acara pernikahan dan acara Lawidi di Pulau Batang Dua.

\section{Fungsi Musik Tali Dua pada Acara Pernikahan}

Pada acara pernikahan, Tali Dua biasanya digunakan untuk mengiringi perjalanan pengantin pria dan wanita dari rumah ke gereja untuk melakukan pemberkatan nikah. Para pengantin yang akan menikah diwajibkan mempersiapkan musik Tali Dua dalam mengiringi perjalanan ke gereja. Perjalanan ke gereja sendiri harus dilakukan tanpa menggunakan kendaraan sambil diiringi musik Tali Dua dengan membawakan lagu-lagu daerah khas Pulau Batang Dua yang memakai bahasa Wayoli bernuansa gembira, seperti lagu Ua ua no manyasal atau jangan-janganlah menyesal. Selain itu, dalam perjalanan dari rumah pengantin menuju gedung gereja, pengantin didampingi oleh keluarga dan masyarakat yang ada di lingkungan sekitar.

Keluarga mempelai perempuan dan keluarga mempelai laki-laki secara bersama membentuk satu kelompok, mengantar pengantin menuju gedung gereja sambil bernyanyi secara bersama lagu-lagu daerah masyarakat Pulau Batang Dua. Pada proses ini ada nilai kebersamaan yang terjalin antara kedua keluarga mempelai, yang awalnya kedua keluarga ini berbeda, namun setelah mengantar mempelai menuju gedung Gereja kedua keluarga ini harus membentuk satu kelompok. Berikut ini pada gambar 2 disajikan kebersamaan keluarga mempelai mengantar pengantin menuju gedung gereja.

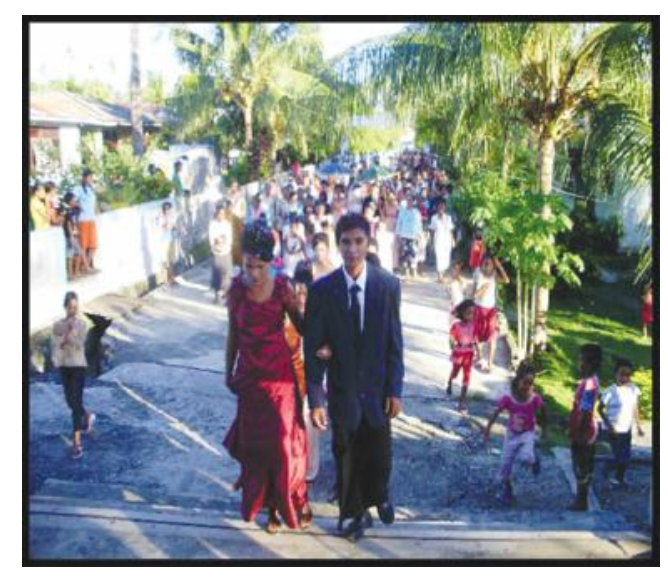

Gambar 2. Kebersamaan keluarga mempelai mengantar pengantin menuju gedung gereja

\section{Fungsi musik Tali Dua pada acara Lawidi menyambut tahun baru}

Budaya Lawidi adalah tradisi atau kebiasan-kebiasan yang dilakukan masyarakat di Pulau Batang Dua dalam berkunjung dan bersilahturahim, baik yang dilakukan oleh satu individu dengan individu lain, satu keluarga dengan keluarga lain, dan atau satu kelurahan 
dengan kelurahan lainnya. Pada pembahasan ini, dijelaskan tradisi Lawidi pada acara menyambut tahun baru antar-kelurahan. Berikut pada gambar 3 diperlihatkan kegiatan tradisi Lawidi menyambut tahun baru.

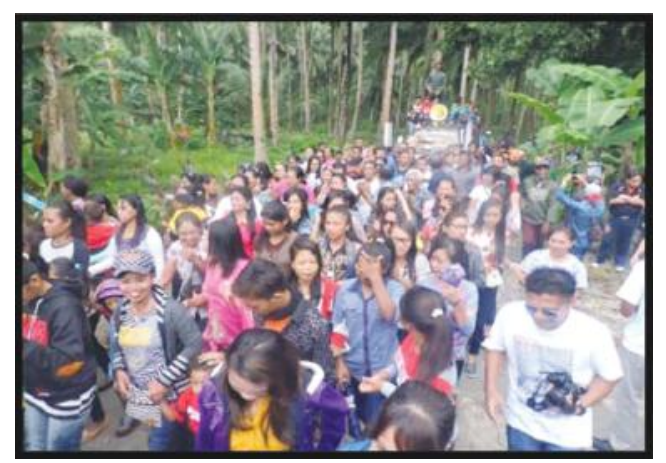

Gambar 3. Acara Lawidi menyambut tahun baru antar-kelurahan

Tradisi Lawidi pada acara tahun baru biasanya dilakukan pada awal bulan Januari, yaitu pada minggu pertama. Acara ini melibatkan pemerintah, Gereja, tokoh adat, tokoh masyarakat, aparat kepolisian, dan seluruh masyarakat yang ada pada satu kelurahan.

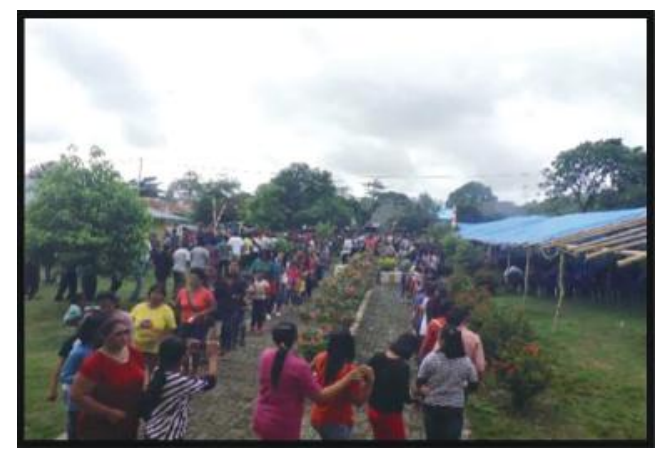

Gambar 4. Ronggeng/menari bersama pihak pemerintah, aparat, Gereja, dan masyarakat.

Musik Tali Dua biasanya digunakan untuk mengiringi perjalanan dari satu kelurahan ke kelurahan lain, sambil secara bersama menyanyikan lagu-lagu daerah setempat sampai tiba di kelurahan yang menjadi tujuan. Misalnya dari kelurahan Mayau menuju ke kelurahan Lelewi, atau sebaliknya dari kelurahan Lelewi menuju kelurahan Mayau. Setibanya di kelurahan tujuan, akan disambut dengan tari-tarian atau nyanyian-nyanyian sambil berjabat tangan satu dengan yang lain. Setelah berjabat tangan, kelurahan tuan rumah akan menjamu tamu dengan makanan dan minuman yang dikumpulkan oleh tiap-tiap keluarga. Selanjutnya, acara puncak berupa ronggeng bersama (menari bersama) antara kedua kelurahan, yang di dalamnya terdiri dari pemerintah, pihak gereja, aparat kepolisian, tokoh adat, tokoh masyarakat, dan seluruh masyarakat yang hadir. Berikut pada gambar 4 disajikan ronggeng atau menari bersama pihak pemerintah, pihak aparat, tokoh gereja, dan seluruh masyarakat pada acara Lawidi menyambut tahun baru.

\section{Nilai Internal Musik Tali Dua}

Nilai internal merupakan nilai yang berasal dari dalam musik Tali Dua itu sendiri, yang berkaitan dengan para pelaku atau pemain musik Tali Dua yang tergabung dalam suatu kelompok.

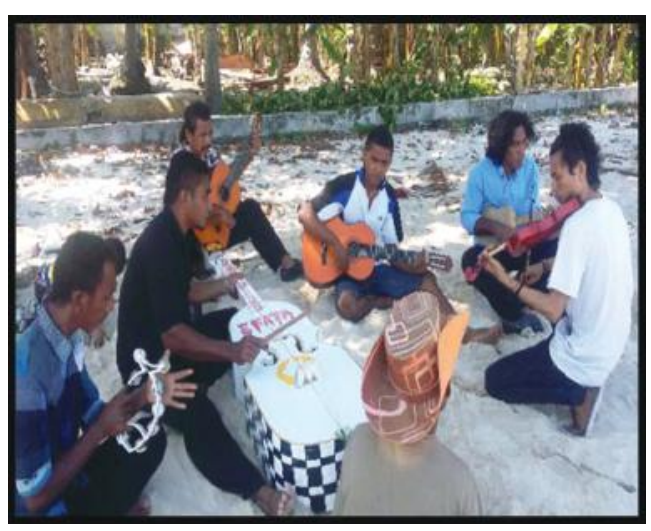

Gambar 5. Kelompok Tali Dua Efata dalam proses latihan

\section{Kelompok Musik Tali Dua}

Kelompok musik Tali Dua seperti yang sudah dijelaskan di atas, terdiri dari lima sampai sepuluh orang. Setiap anggota memiliki peran dan fungsi masing-masing sesuai dengan instrumen yang dimainkan. Salah satu kelompok musik Tali Dua yang masih eksis hingga saat ini adalah kelompok Tali Dua Efata. Kelompok Tali Dua Efata terdiri dari enam orang pemain, yaitu dua pemain gitar, dua pemain ukulele, satu orang 
pemain ceker, dan satu orang pemain bass Tali Dua. Setiap pemain tentunya memiliki karakter masing-masing yang berbeda, begitu pun teknik bermainnya. Karakter pemain ukulele/juk tidak sama dengan karakter pemain bass, begitu juga sebalinya. Berikut pada gambar 5 diperlihatkan kebersamaan anggota kelompok musik Tali Dua di Pulau Batang Dua pada saat melakukan latihan.

Sebelum pementasan kelompok Tali Dua Efata biasanya melakukan latihan agar penampilannya bisa maksimal. Dalam proses latihan, setiap pemain harus memainkan perannya dengan baik, misalnya peran pemain gitar satu (1) dan gitar dua (2) harus harmonis dalam menciptakan ritmis, akord, dan warna suara sesuai karakter lagu yang dimainkan. Begitu juga halnya dengan pemain bass Tali Dua, harus mampu menyeimbangan suara bass dengan suara instrumen lain yang berkapasitas lebih besar. Dengan demikian, setiap pemain harus peka, bekerjasama, saling melengkapi, dan dapat menahan emosinya, sehingga terbentuk suatu harmoni yang baik. Setiap instrumen dalam kelompok musik ini tidak dapat dilepaspisahkan satu dengan yang lain, semua alat musik ini harus menyatu dalam kelompok, sehingga suara yang dihasilkan sesuai dengan karakter musik Tali Dua, bukan karakter musik lain.

\section{Nilai-nilai Pendidikan Multikultural dalam Musik Tradisional Tali Dua}

Berdasarkan uraian di atas, baik tentang latar belakang masalah, konsep pendidikan multikultural, konsep musik tradisi, dan eksistensi musik Tali Dua di Pulau Batang Dua, pada bagian ini dianalisis nilai-nilai yang terkandung dalam musik Tali Dua, khususnya hubungannya dengan pendidikan multikultural. Proses berlangsungnya pendidikan multikultural tidak semata-mata berlaku disekolah formal. Akan tetapi pendidikan sebagai "transmisi kebudayaan" menjadi tanggung jawab bersama termasuk pendidikan nonformal dan informal yang berkaitan dengan nilai-nilai yang ada pada masyarakat dan keluarga (lihat Basri,
2012: 104). Dengan demikian, pembahasan kajian ini mengarah pada nilai-nilai pendidikan multikultural yang ada dimasyarakat, dan dapat digunakan sebagai metode pengalihan dan pewarisan budaya, khususnya yang berhubungan dengan nilai-nilai dalam musik tradisional Tali Dua.

Adapun nilai pendidikan multikultural yang terdapat dalam musik Tali Dua, terlihat dari beberapa hal berikut: (1) nilai pendidikan multikultural berkaitan dengan fungsi Musik Tali Dua pada acara perkawinan di Pulau Batang Dua, (2) nilai pendidikan multikultural berkaitan dengan fungsi musik Tali Dua pada acara Lawidi dalam rangka menyambut tahun baru antar kelurahan, dan (3) nilai pendidikan multikultural berkaitan dengan kelompok musik Tali Dua secara internal. Tiga nilai pendidikan multikultural ini diharapkan menjadi pengetahuan bersama, khususnya membentukan rasa persatuan dan kesatuan, membangkitkan sikap toleransi antar kelompok masyarakat, dan membentuk watak atau karakter generasi muda yang berlandaskan Pancasila.

Penjelasan terhadap masalah yang dibahas ini, dikemas dan dijelaskan pada gambar dalam bentuk bagan pendidikan multikultural melalui musik Tali Dua, sebagai berikut:

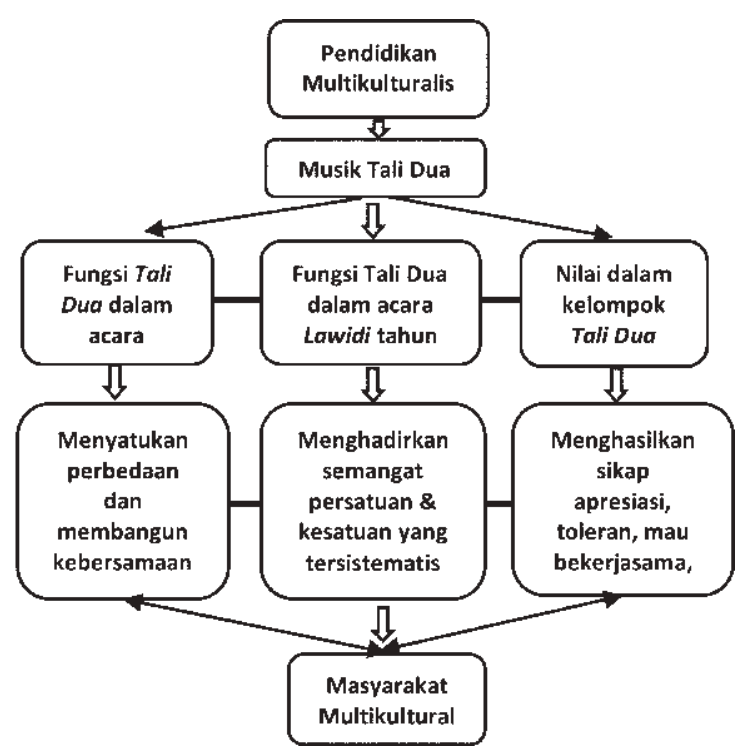

Gambar 6. Bagan pembahasan nilai-nilai pendidikan multikulturalisme 
Nilai Pendidikan Multikultural dalam Fungsi Musik Tali Dua pada Acara Perkawinan

Esensi pendidikan multikultural adalah praktik pengenalan dan penanaman nilai-nilai yang berorientasi pada tujuan terbentuknya kesadaran bersikap dan berperilaku untuk menghargai dan menerima keberagaman atau perbedaan budaya. Ini pernting disosialisasikan atau ditanamkan karena dapat menjadi pengikat persatuan dan kesatuan dalam menjalankan kehidupan bermasyarakat, berbangsa, dan bernegara secara demokratis, tanpa prasangka, tidak diskriminatif, dan menghargai hak asasi (Mahmud dalam Triyanto, 2017: 135).

Pada acara perkawinan, nilai-nilai pendidikan multikultural dapat dilihat pada perjalanan dari rumah pengantin menuju gedung gereja, pengantin didampingi oleh keluarga dan masyarakat yang ada di lingkungan sekitar, maupun dari luar. Keluarga mempelai perempuan dan keluarga mempelai laki-laki secara bersama membentuk satu kelompok, mengantar pengantin menuju gedung gereja sambil bernyanyi secara bersama lagu-lagu daerah masyarakat Pulau Batang Dua dengan iringan musik Tali Dua. Pada proses ini ada nilai kebersamaan yang terjalin antara kedua keluarga mempelai, yang awalnya kedua keluarga ini berbeda, namun pada saat mengantar pengantin menuju gedung Gereja, kedua keluarga ini harus membentuk satu kelompok.

Musik Tali Dua menjadi media dalam konteks perkawinan itu, digunakan untuk mengiringi keluarga mempelai perempuan dan keluarga mempelai laki-laki menuju gedung Gereja, sambil menyanyikan lagu-lagu daerah setempat yang bernuansa riang atau gembira. Pada konteks ini, fungsi musik Tali Dua sebagai musik tradisi seperti yang dijelaskan di atas, dapat memupuk rasa kekeluargaan, memupuk perasaan berada (being) dalam satu komunitas, semangat kebersamaan (Supanggah, 2016). Konteks ini tentunya berkaitan dengan konsep pendidikan multikultural (Mahmud dalam Triyanto, 2017: 135), tentang terbentuknya kesadaran bersikap dan berperilaku untuk menghargai dan menerima keberagaman atau perbedaan budaya setiap keluarga mempelai yang awalnya berbeda itu, dapat membuka hati, saling menerima, dan melebur membentuk keluarga besar yang bukan lagi dua melainkan satu.

Tiap-tiap keluarga pengantin telah menyadari untuk membuka hati, bersikap dan berperilaku, menerima dan saling menghargai antara satu dengan yang lain. Ini akan membentuk pemahaman bersama terhadap pendidikan multikultural yang dilakukan turun-temurun pada setiap generasi di Pulau Batang Dua, dan akan menghasilkan manusia-manusia yang berkarakter dan berwawasan budaya bhineka tunggal ika, yakni memiliki sikap saling menghargai, toleran terhadap budaya lain, mencintai sesama, dan bertindak atas dasar semangat solidaritas yang tinggi.

\section{Nilai Pendidikan Multikultural dalam Fungsi musik Tali Dua pada Acara Lawidi}

Seperti yang telah dijelaskan sebelumnya, Lawidi adalah tradisi atau kebiasan-kebiasan yang dilakukan masyarakat di Pulau Batang Dua dalam berkunjung dan bersilahturahim, baik yang dilakukan oleh satu individu dengan individu lain, satu keluarga dengan keluarga lain, dan atau satu kelurahan dengan kelurahan lain. Tradisi Lawidi pada acara tahun baru biasanya dilakukan pada awal bulan januari, yang melibatkan pemerintah, gereja, tokoh adat, tokoh masyarakat, aparat kepolisian, dan seluruh masyarakat yang ada pada satu kelurahan. Musik Tali Dua biasanya digunakan untuk mengiringi perjalanan dari satu kelurahan ke kelurahan lain, sambil secara bersama menyanyikan lagu-lagu daerah setempat sampai tiba di kelurahan yang menjadi tujuan.

Pada saat menyanyikan nyanyian atau lagu-lagu daerah Pulau Batang Dua, ada nilai kebersamaan yang timbul di antara sesama kelompok itu, sebab nyanyian melalui teks, ekspresi, dan melodi, memiliki kemampuan menyatukan perasaan bagi pelakunya. Hal ini sesuai yang diungkap Barthes (1990), bahwa partikel bunyi yang berkaitan dengan musik adalah tubuh ketika suara itu dinyanyikan, tangan ketika suara itu ditulis, dan lidah ketika suara itu diucap. Ketika ditangkap dan 
dirasakan 'partikel bunyi dasar' tersebut dalam sebuah musik lalu berusaha menteorikannya (perkawinan teks dan karya), ini berarti orang menggali suatu nilai yang tersembunyi, sehingga menghasilkan rasa suka atau tidak suka. Pendapat ini menunjukkan bahwa dalam membawakan atau menyanyikan sebuah karya musik, baik teks maupun instrumennya, akan menghasilkan sebuah perasaan kagum di antara pelakunya, yang berdampak pada rasa kebersamaan mereka.

Tradisi Lawidi menjembatani masyarakat melakukan hubungan sosial, yang dilakukan antar-satu kelurahan dengan kelurahan lainnya. Pada saat menyanyikan lagu-lagu daerah, seperti yang dijelaskan sebelumnya, seluruh elemen menyatu, baik pemerintah, gereja, tokoh adat, tokoh masyarakat, aparat kepolisian, dan seluruh masyarakat yang terlibat. Kegiatan ini berlangsung dengan penuh kedamaian dan rasa solidaritas yang tinggi, yang dibangun anatara elemen-elemen maasyarakat dimaksud. Hal ini sesuai dengan yang dijelaskan di atas tentang konsep pendidikan multikultural, yaitu sikap menerima keanekaragaman atau perbedaan budaya ini penting disosialisasikan atau ditanamkan karena itu dapat menjadi pengikat persatuan dan kesatuan serta kesetaraan dalam menjalankan kehidupan bermasyarakat, berbangsa, dan bernegara, secara demokratis, tanpa prasangka, tidak diskriminatif, dan menghargai hak asasi (Mahmud, dalam Tryanto, 2017: 135).

Hal penting yang digaris bawahi pada kegiatan tradisi lawidi dalam rangka menyambut tahun baru ini adalah menyatunya elemenelemen bangsa yang tidak diskriminatif, tetapi demokratis, yang ditunjukkan dengan menyatunya pihak pemerintah, pihak agama (gereja), tokoh masyarakat, tokoh adat, dan seluruh anggota masyarakat. Oleh karena itu, sebagai nilai-nilai pendidikan multikultural yang dapat dilihat pada tradisi Lawidi ini adalah terciptanya suatu sistem yang kuat terhadap sikap menghargai keberagaman, tidak ada perbedaan yang diakibatkan hanya karena beda strata sosial, beda jabatan, melainkan bersatu padu membangun sistem yang kuat, yang dimulai dari atas sampai pada masyarakat kecil.
Hal itu menimbulkan sikap apresiasi terhadap keberagaman, terhadap kemajemukan, dan perbedaan. Bahwa perbedaan bukan membedakan, tetapi perbedaan justru menyatukan.

Berdasarkan hal di atas, Sutrisno (2010) menawarkan pendekatan budaya dengan melihat suatu realitas dari masyarakat dari sudut pandang mentalitas orang, nilai yang diacu suatu individu secara bersama, yang mana penyatuan nilai merekatkan bangsa majemuk dengan keikaan, saling hormat menghormati, toleransi pada perbedaan, serta hak hidup etnik, baik agama dan golongan tertentu tanpa saling mendeskriminasikan satu seam yang lain. Bahwa perbedaan adalah kekayaan bangsa yang harus dijaga dan dilestarikan.

\section{Nilai Pendidikan Multikultural Berkaitan dengan Kelompok Musik Tali Dua secara Internal}

Nilai pendidikan multikultural pada kelompok musik Tali Dua ini dapat dilihat pada sikap saling memahami, mengapresiasi kelebihan orang lain, menahan diri dari sifat egoistis, dan mampu bekerja sama. Sebab jika pemain musik Tali Dua dalam satu kelompok tidak mengutamakan sikap apresiasi dan kerjasama, maka keharmonisan tidak dapat dicapai. Baik yang berkaitan dengan keharmonisan musiknya maupun nilai kebersamaan antar-anggota. Keharmonisan musik dimaksud adalah nilainilai keindahan yang dihasilkan dari bunyi musik Tali Dua, pada saat dimainkan. Nilai keindahan menurut Smits (2016), memiliki kemampuan menyatakan, mewujudkan, dan mengekspresikan seluruh eksistensi manusia.

Hal di atas menunjukkan, bahwa, kelompok musik Tali Dua memiliki nilai multikulturalisme yang tinggi untuk memahami, menghargai, bekerja sama, dan menekan sifat egoisme. Nilainilai itu sesuai dengan penjelasan Supanggah (2016), bahwa nilai tradisi mampu menekan dan mengurangi sifat dan sikap ke-egoisan atau individualistis, mempertinggi sikap toleransi, kelenturan, tenggang rasa, dalam hidup bermasyarakat, pengendalian emosi, tidak cepat marah atau tersinggung gara-gara hal yang 
"sepele", dan sebagainya.

Pada ranah apresiasi seni hal ini di maknai sebagai tindakan sosial untuk mengenali, memahami, menikmati, dan menghargai di sini mempersyaratkan tiadanya sikap apriori (tanpa prasangka), kepedulian, perhatian, dan kesadaran seseorang, merupakan model budaya yang tepat dalam membangun kesadaran menghargai dan menerima keanekaragaman atau perbedaan berbagai jenis, bentuk, corak, atau gaya seni (Triyanto, 2017: 136).

Selain itu, apresiasi dalam satu kelompok musik Tali Dua juga berkaitan dengan kemampuan anggota kelompok memahami tingkat kemampuan musikal masing-masing. Dengan kata lain, setiap kemampuan bermusik yang ada harus digunakan untuk saling mengisi dan saling melengkapi antara satu dengan lainnya. Sebab kemampuan musikal seseorang yang berkaitan dengan apresiasi musik, dapat di capai tergantung sebesar-besarnya sikap mendengar seseorang (Miller, 2017: 9). Proses apresiasi musik akan membentuk akhlak dan moral seseorang untuk lebih menghargai dan memahami orang lain. Dalam konteks pendidikan multikultural, proses apresiasi berkaitan erat dengan penghargaan terhadap budaya orang lain.

\section{KESIMPULAN}

Pendidikan multikultural merupakan sebuah paradigma atau ideologi pendidikan yang sangat penting diimplementasikan pada konteks kehidupan bangsa Indonesia sebagai bangsa yang beragam dan majemuk. Pendidikan mutikultural menuntut pelakunya memiliki pemahaman yang menyeluruh terhadap keberagaman dan perbedaan budaya, yang di aplikasikan dalam tindakan nyata, yakni mampu menghargai dan menghormati keberagaman itu.

Pada segi lain, pendidikan multikultural menjadi sangat penting untuk menghadirkan semangat persatuan dan kesatuan bangsa yang tersistematis dengan baik, mulai dari atas sampai pada masyarakat kecil. Artinya, pendidikan multikulturalisme harus dilakoni oleh seluruh elemen bangsa, mulai dari pemerintah, tokoh agama, tokoh masyarakat, dan seluruh anggota masyarakat yang ada, baik tua maupun muda.

Salah satu nilai pendidikan multikulturalisme dapat dilihat pada musik tradisi yang mampu memupuk rasa kekeluargaan, memupuk perasaan berada (being) dalam satu komunitas, semangat kebersamaan, kegotong royongan dengan tidak mengedepankan pamrih pribadi, menekan dan mengurangi sifat dan sikap keegoisan atau individualistis, mempertinggi sikap tolerans, kelenturan, tenggang rasa, dalam hidup bermasyarakat, pengendalian emosi, tidak cepat marah atau tersinggung gara-gara hal yang "sepele", dan sebagainya.

Nilai-nilai musik tradisi ini terdapat juga pada musik tradisi Tali Dua, yang merupakan musik tradisional masyarakat Pulau Batang Dua, Ternate, Maluku Utara. Nilai-nilai ini dianalisis dalam konteks pendidikan multikultural sebagai pranata sosial yang menekankan pentingnya sikap menghargai dan toleransi terhadap keberagaman budaya, etnis, suku, bahasa, sistem kepercayaan, dan kesenian tradisi di Indonesia. Hal ini dapat dianalisis dari pemfungsian musik Tali Dua maupun pada kelompok Tali Dua itu sendiri. Pada fungsi musik Tali Dua nilai-nilai pendidikan multikultural berkaitan dengan nilai kesatuan dan persatuan bangsa, menimbulkan rasa kebersamaan, saling menerima, saling mencintai, dan tidak membeda-bedakan strata sosial sebagai pemisah persatuan itu.

Sedangkan pada kelompok musik Tali Dua, nilai-nilai pendidikan multikultural dapat dilihat pada perilaku hormat menghormati, sikap toleransi terhadap perbedaan, dan mengutamakan kepentingan bersama dari pada sifat egoisme. Dengan demikian nilai pendidikan multikulturalisme pada musik Tali Dua adalah menghasilkan manusia-manusia Indonesia yang mencintai budaya bangsa, berwatak nasionalisme kebangsaan, bermoral toleransi, menghargai budaya daerah lain, mengapresiasi budaya lain, memiliki karakter berdasar kebhinekaan, dan menjaga semangat persatuan dan kesatuan bangsa sebagai harga mati. 


\section{DAFTAR PUSTAKA}

Barthes, R. 2010. Imaji Musik Teks. Terjemahan. Jalasutra: Yogyakarta

Basri, H. 2012, Kapita Selekta Pendidikan. Bandung: Pustaka Setia

Hastanto, S. 2005. Musik Tradisi Nusantara. Jakarta: Kementerian Kebudayaan dan Parawisata.

Miller, H.M. 2017. Apresiasi Musik. Thafa Media: Yogyakarta

Jazuli, M. 2001. Manajemen Produksi Seni Pertunjukan. Yogyakarta: Lentera Budaya

Rohidi, T.R. 2014. Pendidikan Seni, Isu, dan Paradigma. Semarang: Cipta Prima Nusantara
Rohidi, T.R. 2011. Metode Penelitian Seni. Semarang: Cipta Prima Nusantara Sunarto. 2016. 8 Tokoh Semiotika. Yogyakarta: Panta Rhei Books

Sutrisno, M. 2009. Ranah-ranah Kebudayaan Dalam Esay. Yogyakarta: Kanisius

Supanggah, R. dkk. 2016. "Membumikan Seni Pertunjukan Tradisional”, Makalah Seminar Nasional UNNES.

Triyanto. 2017. Spirit Ideologis dalam Penidikan Seni. Semarang: Cipta Prima Nusantara. Waesberghe. V.S. 2016. Estetika Musik. Editor Sunarto. Yogyakarta: Thafa Media. 